\title{
Criminal Aspects Specific to Corruption Offenses
}

\author{
Lucia Cerasela Balan \\ Faculty of Economic Sciences and Public Administration, Law specialization, University "Stefan cel Mare” Suceava, \\ Romania, Master in Criminal Sciences at "Dimitrie Cantemir" Christian University of Bucharest, Romania \\ Lucya_9212@yahoo.com
}

\begin{abstract}
Corruption is one of the main topics of discussion in any field and at any level, representing one of the greatest challenges of the contemporary world. This is present both in poor and developing and developed countries, and the fight to combat it has become a serious problem, especially as the phenomenon expands very rapidly, including, firstly, a few sectors, a few domains, and then the whole of society, becoming a lifestyle, a mentality, a labyrinth from which it can no longer come out. The diminution of the phenomenon is possible in a knowledge society, with individuals having an irreproachable moral conduct, based on education, built on the most durable elements of morality and consciousness which mankind has accumulated over time to the form of today of our civilization. Corruption is perceived by most segments of the population as a serious and dangerous phenomenon that undermines the structures of power and authority and violates the expectations of many people as to the subsequent evolution of social life into living standards.
\end{abstract}

KEYWORDS: corruption, crimes, economic, officials, phenomenon

\section{Introduction}

Corruption has existed since ancient times, which is by far one of the most serious and widespread behaviors of certain civil servants. This social phenomenon is a disruptive factor for democracy and the rule of law. Updating the issue is particularly necessary due to the negative impact of corruption on state democracy, social equity, justice and respect for human rights and fundamental freedoms.

The history of human society shows that criminality and corruption in all its forms have also taken place with various extensions and intensities from ancient times. As continuous processes, these phenomena are manifested today in all countries and social structures, regardless of their economic development depending on the socio-political changes and the approach of the bodies of state power.

Unlike the laws of other states in our legislation, there is no text to criminalize an offense called "corruption", but the legal literature includes this notion in a broad sense, many violations of the sphere of criminal law in respect of the service. Designed in the popular sense, corruption is the abuse of power in their own advantage. Therefore, it seeks to identify those lawyers who involve corruption offenses that is to say for unlawful profits.

\section{Criminal aspects specific to corruption offenses}

By attempting to systematize the causes and conditions which still favor the commission of crimes that affect activities of public interest or other activities regulated by the law, and in particular those of corruption, one can distinguish: economic and social causes and causes of educational and psychological nature (Dobrinoiu 1983, 16).

Economic and social realities - the unequal distribution of the social product, the differences between physical and intellectual work, between qualified and unskilled labor, living conditions in the urban and rural areas - are likely to create a climate favorable to the emergence of antisocial manifestations, consisting of and acts of corruption of officials (Tamaş, Antoniu, Hentea 1972, 33).

Moral, educational and psychological causes and conditions play an important role in determining and favoring corruption. Remnants of bourgeois education and skills - such as individualism, cupidity, selfishness, careerism, abuse, tendency to seize, parasitism - continue to be present both in the conscience of some citizens and in the conscience of some officials.

Representing a complex issue whose manifestations, social consequences and ways of settlement are of interest to both public opinion and the institutionalized level of social control, corruption is conceived by most honest social segments as a particularly serious and dangerous 
phenomenon capable of undermining power structures, achieving economic reform, raising the standard of living of the population, and hoping for the country's evolution towards the rule of law.

In its classical sense, corruption denotes the abuse of power for personal benefit, inside or outside that institution. In line with this legal-criminal sense, the organs of the criminal justice system reduce the scope of corruption offenses only to acts and acts committed by officials during or in connection with the service. This view is also in line with the position adopted by international institutions in this field (Dobrinoiu 1995, 25).

Corruption begins by concealing or distorting reality to achieve certain results that cannot be achieved by promoting truth and continuing with the clientele system of positioning and promotion on criteria other than probity, competence and honor. Corruption may also be aimed at obtaining material or other advantages through "criminal activities of conspiratorial groups in order to obtain important illicit income" (Nistoreanu and Păun 2000, 228).

Corruption can take on various forms at a political, administrative and economic level, diversity that directly influences the intensity of public perception of this phenomenon:

1. Administrative corruption - the most widespread, which tends to be the act of a clerk claiming a reward for making an act to which he is bound by his office, until personal misappropriation of public property committed by persons in key positions of the state administration. In principle, civil servants commit circumvention of statutory public procurement regulations, favor certain enterprises or firms in distributing contracts (sometimes with a percentage of their benefit as bribes), falsification of tender documents, legal division of premises or dwellings, interventions in addition to other civil servants to overlook the violation of law, etc.

2. Political corruption - is manifested especially in the form of pressure and even selfindulgence on officials to determine them to make certain illegal or lawful decisions (which violate moral norms). It may seek to obtain material or other advantages. Illicit actions are mainly done in inter-relational forms, more or less complicated, which illustrate the term "crime organization" and the term "white collar crime", as American criminologist Edwin Sutherland claims, "in the general profession, the function creates the context, the occasion and sometimes even the motivation of committing the offenses, the transposition of the illicit facts into direct or indirect realization within a relational ensemble. The social position of the person, as well as his socio-economic-political engagement, impedes the realization of criminal justice" (Nistoreanu and Păun 2000, 254).

3. Economic corruption - comprises a very broad spectrum of "money laundering", which designates the reinvestment in licit business of money obtained from illicit business, using intricate domestic and international financial circuits, financial evasion, fraudulent bankruptcy, trafficking licensing, non-payment of customs duties and taxes, falsification of checks and the issuance of uncertified checks, the exercise of larger commercial additions, speculation and economic and commercial activities, and other such underground transactions consisting of unfair competition, smuggling of goods. Massive and unscrupulous aggression by thefts, fraudulent management, embezzlement, and other forms of "economic vandalism" by criminals through the use of abusive methods is accompanied in most cases by acts of corruption. Thus, in the productive branches of the economy, corruption encompassed the entire privatization process, especially the illegal patrimony transfers, by sub-evaluation, from state trading companies and autonomous administrations to private entrepreneurs; conditioning the delivery of goods, accepting poor quality products in exchange for material advantages consisting of amounts of money, goods or share of the business.

The criminological investigation of the phenomenon of corruption has as its immediate objective the identification and explanation of the objective and subjective causes that lead to the committing of such antisocial acts and, as a final, the proposal of effective measures and programs to prevent and combat this phenomenon. There is a causal complexity of the genesis of corruption as a whole and of various concrete forms of manifestation, in the light of which not only the current criminal explosion can be explained, but also its likely evolution.

Specialists argue that this complex and universal phenomenon is always the expression of a certain socio-cultural context, so that the transformations produced in Romanian society in recent years have revealed the lack of solid moral principles and a reduced sense of responsibility to some 
individuals, to destructive processes. However, most authors consider the main sources of this phenomenon: the perpetuation of poor political, economic and normative structures; increasing economic and social difficulties and increasing social and normative tensions among individuals, groups and social institutions. (Buneci, Butoi and Butoi 2002, 57).

Corruption induces a significant discrepancy between social, cultural and normative patterns and the legitimate expectations of individuals and social groups, representing an antisocial phenomenon with profound negative consequences. Undoubtedly, the main cause of the rise of corruption, as a social phenomenon, lies in the political area. Political incoherence has been greatly manifested in the adoption of laws necessary for the functioning of the rule of law and, in particular, of laws designed to ensure the proper framework for the conduct of economic life. Corruption was also encouraged by the lack of unity of political parties in the area of protection of perennial social values, the failure to apply the criterion of professionalism and competence in the occupation of civil servants seriously affecting the activity of the state administration and, implicitly, the institutions competent to detect or sanction corruption.

Another major cause of corruption at the macro-social level is also an inheritance from the old regime - generalized poverty. This gives some tolerance to this phenomenon, as well as the lack of well-defined social groups that support values opposite to corruption. Corruption is also generated and amplified by the decentralization of decisions and administrative structures, functional autonomy and economic liberalization at the level of the public institutions and economic agents, in the conditions of the lack of firmness and authority of the control bodies, as well as in the direct involvement in corruption acts and other offenses of those designated to enforce the law. Consequently, subjective causes must be sought in how individuals have perceived and assimilated information in the context of social change.

Romania's entry into the European Union on January 1, 2007 had a major impact on the country, so one of the most visible concerns was corruption, which the European Union identified as an acutely vulnerable point. In June 2007, the European Commission's Report assessed Romania's progress in corruption issues and highlighted the fact that, although the Government has successfully completed the procedures for initiating laws, action plans and programs, at the practical level there have not been felt significant changes.

The evolution of the phenomenon is in close concession with the dynamics of the whole social ensemble, constituting an indirect reflection of its deficiencies and malfunctions. Social, cultural, legal and political prevention must be resolute, uncompromising transparent and carried out in a legal framework, respecting human dignity and the presumption of innocence, under the eyes and control of civil society. The socio-cultural plan includes education and culture, the promotion of human and cultural values. Without the support of the honest man, non-governmental organizations, and trade unions to prevent corruption, this phenomenon will continue to evolve like a social cancer that will maintain and worsen society's drift. In legal and political terms, there are many punitive instruments to combat corruption in all its forms, and the promptness and efficiency of the control institutions are likely to ensure that social relationships are unfolding far from any disruptive element (Cherciu 2004, 41).

Also, combating it can only be effectively achieved by economic, political and moral recovery of society as a decisive prerequisite for ensuring that the law is respected by citizens by improving decent living measures combined with a constant concern for law enforcement criminal.

\section{Conclusions}

Defining corruption is reflected in Romanian legislation by defining distinct offenses that fall within the generic term of corruption, such as: giving and taking bribes, influencing traffic, buying influence. Bribery is not a simple participation in bribery crime, but a distinct, self-serving offense correlative with bribery (Cristiean 2017, 162). The ambiguity with which the term corruption is used makes it difficult to establish a real public debate, in which most of the times a number of unclear laments can be identified. With all the diversity of definitions, the essence of corruption is determined by the use by a member of a public organization of its position in the organization or its 
resources for private purposes. These acts are deliberate, and the person who gives or takes the bribe and who uses the resources of the public organization for private purposes makes them perfectly aware even though they sometimes disagree with these practices. It is especially the case of those who have to give bribes to get certain services that they should benefit from without making personal favors to members of public organizations.

\section{References}

Buneci, P., Butoi, I.T., and Butoi, T. 2002. Socio-legal elements of social control on the field of special deviance. Bucharest: Romania of Tomorrow Publishing House.

Cherciu, E. 2004. Corruption-Characteristics and Particularities in Romania. Bucharest: Lumina Lex Publishing House.

Cristiean, V. 2017. Criminal Law. Special Part. Bucharest: Universul Juridic Publishing House.

Dobrinoiu, V. 1983. Trafficking in the Function and Influence in Criminal Law. Bucharest: Scientific and Encyclopaedic Publishing House.

Dobrinoiu. V. 1995. Corruption in Romanian Criminal Law. Bucharest: Atlas Lex Publishing House.

Nistoreanu, G.and Paun, C. 2000. Criminology. Bucharest: Nova Publishing House.

Sutherland, E. 1949. White Collor Crime. New York: Dryden Press Publishing House. 